\title{
Organic farming: knowledge, practices, and views of limited resource farmers and non-farmers on the Delmarva Peninsula
}

\author{
Lurline Marsh • Virginie Zoumenou • Corrie Cotton • \\ Fawzy Hashem
}

Received: 2 September 2015 / Accepted: 3 February 2016 /Published online: 16 February 2016

(C) The Author(s) 2016. This article is published with open access at Springerlink.com

\begin{abstract}
Gaps in knowledge on organic agriculture are a challenge for some stakeholders, including limited resource farmers on Delmarva Peninsula of USA. A survey of limited resource farmers and non-farmers in this region and neighboring counties was conducted to identify their knowledge, practices, perceptions, and needs. Most of the respondents were farmers; fewer than $30 \%$ grew both organic and inorganic crops, and less than $10 \%$ grew only organic crops. Organic commodities produced were fruits, vegetables, herbs, and animals. At least $60 \%$ of the farmers had some knowledge about production costs, marketing, and farming practices for organic crops, while nearly $50 \%$ did not know about the practices for growing certified organic. Lack of time and the length of time to certify for organic farming were the two most cited reasons for farmers not growing organic. Both the farmers and non-farmers believed that organic crops are safe, high quality, and high cost. Some non-organic farmers and non-farmers desired to do organic farming, but needed information such as production techniques and costs. This survey indicates a need to provide some farmers and nonfarmers with more information on how to become active in organic production in this region and suggests a continued need for policies to make organic production more amenable to adoption by producers.
\end{abstract}

L. Marsh $(\bowtie) \cdot$ V. Zoumenou $\cdot$ C. Cotton $\cdot$ F. Hashem University of Maryland Eastern Shore, Princess Anne, MD, USA e-mail: lemarsh@umes.edu
Keywords Organic $\cdot$ Limited resource farmer . Knowledge and perception

\section{Introduction}

Consumers' demands for organic products continue to rise (ERS 2014; OTA 2015) at the regional and national levels in the USA, and globally as people become more conscious about their health, quality of the foods they eat, and the environment in which the foods are grown (EUFIC 2013; Shafie and Rennie 2012). Organic food and non-food products commanded an $11.3 \%$ increase in sales between 2013 and 2014 and organic sales are now nearly $5 \%$ share of the USA total food market (OTA 2015).

Produce inclusive of fruits and vegetables is the top seller in this category, accounting for $43 \%$ of total organic sales in 2012 (Greene 2014). Concomitantly, organic farming continues to be a growing segment of US agriculture, and certified organic crop land accounted for about $0.7 \%$ of US cropland in 2011 (Greene 2013). However, shortage of supplies is a major challenge for the industry with organic farms struggling to keep up with growing demands (Dimitri and Oberholtzer 2009; OTA 2015) and producers in some regions facing unique challenges. For the Delmarva, information is deficient on what limited resource farmers are growing organically, or what their knowledge and perception are on organics. Located $\left(8.5^{\circ} \mathrm{N}, 75.6^{\circ} \mathrm{W}\right)$ between the Chesapeake Bay on the west and the Atlantic Ocean on the east, the Delmarva Peninsula comprises all of Delaware and the 
eastern portions of Maryland and Virginia and has a farming community, which is typically characterized by a large poultry industry mixed with agronomic and horticultural crops. Additionally, this region has increasing populations of baby boomers, retirees, and beach resorters and is in close proximity to large markets in the northeast USA such as Philadelphia, Baltimore, Wilmington, and Washington, DC.

Previous survey of Delmarva residents in the 1990s revealed that availability and price were the main obstacles to consumers not buying organics (Byrne et al. 1992). Noteworthy was the fact that consumers did not know whether they were purchasing organic or not and had no compelling motivation for organics even though they were known as exempt from pesticide residues. Current data on consumer's perceptions continue to be collected and are available for many regions; however, there is a paucity of information on limited resource farmers' opinions, knowledge, perceptions, and use of organics in this region. Data from other regions show that some farmers are reluctant to transition to organic mainly for economic reasons (Farmer et al. 2014), and that organic growers face problems such as time constraints, marketing, organic certification, and a need for more organic education (Agunga and Igodan 2007; Suvedi et al. 2010; Middendorf 2007). This knowledge is essential in helping farmers to make decisions about production and marketing of their commodities at the local or domestic level. Information on consumer attributes in other regions show mixed opinions about some characteristics of organics, but the general impression is one of healthy and environmentally friendly products (Onyango et al. 2007; Yue and Tong 2009; EUFIC 2013; Shafie and Rennie 2012). Consumers' organic knowledge, preferences, and needs in this region are also unknown. Therefore, a necessity exists to assess farmers' and non-farmers' current knowledge of organic produce as well as small farmers' organic crop practices in order to make reliable projections for the contribution of the region to meet the growing organic demands. The region has a small-scale, limited-resource, program at the University of Maryland Eastern Shore where a list of attendees to its annual small farm conferences for the region is available. Hence, the objective of this study was to determine the organic practices, knowledge, perceptions, preferences, and needs of the participants at the University of Maryland Eastern Shore annual conference and consequently on the Delmarva Peninsula and neighboring counties.

\section{Methods}

A cross-sectional design was used. An 18-question survey was developed by extension and research personnel to assess conference participants at the University of Maryland Eastern Shore Annual Small Farm Conference about their knowledge of farming practices, their needs, and their perception of growing organic produce. A non-probability sampling method was used. A convenience sample was made up of farmers who were easy to reach during the Small Farm annual conference and through the annual conference mailing list. The majority of the participants of this conference were small farmers in the Delmarva area. This sampling method does not allow the research team to estimate the extent to which sample statistics are likely to differ from population parameters. The survey was tested and retested with 22 self-convenient participants recruited in 2008. It was revised for clarity and mailed in April 2009 to 300 participants using the small farmer conference list serve. Small farmers were identified using the USDA criteria: farmers with gross sales of less than $\$ 250,000$, by Hoppe et al. 2007). In this study, the term small farmer also refers to limited resource farmer. The three-page survey comprised three main sections: (1) demographics and farming experience (questions 1-3); (2) farmers' experiences, practices, and knowledge (questions 4-13); and (3) perceptions, use, preference, needs, and comments of farmers and non-farmers (questions 14-18). One open-ended question was used to collect any additional comments from the respondents. Levels of knowledge and perception/beliefs were measured on Likert scales of 1-3 and 1-4, respectively. Farmers completed all questions and non-farmers completed only questions $1-3$ and 14-18. In this survey, farmers plus non-farmers are considered as consumers. Data were analyzed using SPSS statistics version 22 to determine frequencies, means, and standard deviations, and SAS 9.3 to conduct analyses of variance. The proposed project was reviewed and approved by the university's Internal Review Board prior to implementation.

\section{Results and discussion}

Demographics and farming experience

Seventy-one of the 300 mailed surveys were completed and returned (approximately $24 \%$ ). The participants 
came from 12 counties out of 14 counties on Delmarva Peninsula (73\%). In addition, some participants (27\%) also came from six counties located in the Peninsula neighborhood (four in Maryland, two in Virginia). Most of the respondents $(71.8 \%)$ were engaged in farming, over 40 years old, and predominantly white (Table 1). The majority $(82.5 \%)$ of this farming group were also older than 40 and included more males than females (Table 2). In contrast, the non-farming group comprised more females than males. According to the small farm program, nearly all the farmer respondents on the list serve fell under the limited-resource category of $\$ 105,000$ or less in sales based on the farm category cited (personal communications).

Farmer's experiences and practices

The majority of farmers had at least 5 years of farming experience (Table 3). When asked to select from a list the specific fruits, vegetables, herbs, and animals that they produce, $43 \%$ produced livestock. This included goats, pigs, sheep, cows, horses, and poultry, which was the most popular animal grown. Less than $10 \%$ of farmers were involved in organic livestock production. Overall, more than $70 \%$ grew some kind of crop in their farming practice. Our findings show a higher percent of farmers collectively producing organic crops $(9.8 \%)$ and mixed organic plus non-organic crops $(29.4 \%)$ than organic farm animals. For the fruits and vegetables category, $33 \%$ produced this commodity organically compared to less than $10 \%$ for livestock. This is not

Table 1 Demographics of survey respondents $(N=71)$

\begin{tabular}{lll}
\hline Demographic & Characteristic & Percent \\
\hline Gender & Male & 53.5 \\
& Female & 46.5 \\
Age (years) & $\leq 24$ & 1.4 \\
& $25-40$ & 18.3 \\
& $41-55$ & 31.0 \\
Race & $>55$ & 49.3 \\
& Black & 18.3 \\
& White & 66.2 \\
Farming experience & Other & 7.0 \\
& No response & 8.5 \\
& Yes & 71.8 \\
& No & 28.2 \\
\hline
\end{tabular}

Table 2 Characteristics of farming and non-farming respondents by age and gender percent $(N=71)$

\begin{tabular}{llllll}
\hline \multirow{2}{*}{ Age } & \multicolumn{2}{l}{ Farming } & & & \multicolumn{2}{l}{ No farming } \\
\cline { 2 - 3 } \cline { 6 - 6 } & Male & Female & & Male & Female \\
\hline$\leq 24$ & 0 & 1.4 & & 0 & 0 \\
$25-40$ & 5.6 & 5.6 & & 1.4 & 5.6 \\
$41-55$ & 15.5 & 9.9 & & 1.4 & 5.6 \\
$>55$ & 22.5 & 11.3 & & 7.0 & 7.0 \\
\hline
\end{tabular}

surprising and aligns with national trend of fruits and vegetables as the top selling organic category of total organic sales in 2012 (Greene 2014). Many consumers are introduced to organics through purchase of organic fruits and vegetables (Pearson et al. 2010). Since organically produced horticultural crops were the focus of this study, the survey also included follow-up questions on selected fruits, vegetables, and herbs.

Growers of organic commodities produced an array of fruits, vegetables, herbs, and raised some animals (Table 4). Among growers, the most popular organic horticultural crop produced was tomatoes by $21.5 \%$, followed by organic peppers, cucumbers, green beans, watermelons, and cantaloupes $(19.6 \%)$. While this

Table 3 Farmers' experience in farming and their farming activities $(N=51)$

\begin{tabular}{lll}
\hline Parameter & Category & Percent $^{\mathrm{a}}$ \\
\hline Years of experience & $<4$ & 21.6 \\
& $5-9$ & 21.6 \\
& $10-14$ & 11.8 \\
& $\geq 15$ & 41.1 \\
& No response & 3.9 \\
Farming activity & Livestock & 43.0 \\
& Organic livestock & 9.8 \\
& Organic and non-organic crops & 29.4 \\
& Non-organic crops only & 35.2 \\
& Organic crops only & 9.8 \\
& Organic fruits and vegetables & 33.0 \\
Crops produced & No crops & 8.2 \\
& Selected fruits & 33.3 \\
& Selected vegetables & 58.8 \\
& Selected herbs & 25.5 \\
a Percent exceeds 100 as respondents could check more than one \\
category & Other unlisted crops & 9.8 \\
\hline
\end{tabular}


Table 4 Percent of farmers producing organic $(\mathrm{Org})$ and non- organic (Non) horticultural crops $(N=51)$

\begin{tabular}{|c|c|c|c|c|c|c|c|c|}
\hline \multicolumn{3}{|l|}{ Vegetables (\%) } & \multicolumn{3}{|l|}{ Herbs $(\%)$} & \multicolumn{3}{|l|}{ Fruits $(\%)$} \\
\hline & Non & Org & & Non & Org & & Non & Org \\
\hline Tomato & 43.1 & 21.5 & Basil & 23.5 & 15.6 & Apples & 5.8 & 1.9 \\
\hline Pepper & 37.2 & 19.6 & Chive & 11.7 & 9.8 & Peach & 5.8 & 1.9 \\
\hline Cucumber & 33.1 & 17.6 & Green onion & 7.8 & 5.8 & Pear & 5.8 & 1.9 \\
\hline Green bean & 27.4 & 15.6 & Cilantro & 7.8 & 9.8 & Blueberry & 9.8 & 3.9 \\
\hline Watermelon & 23.5 & 17.6 & Rosemary & 11.7 & 5.8 & Raspberry & 5.8 & 1.9 \\
\hline Cantaloupe & 29.4 & 19.6 & Oregano & 9.8 & 5.8 & Strawberry & 13.7 & 5.8 \\
\hline Spinach & 17.6 & 9.8 & Thyme & 9.8 & 7.8 & Blackberry & 9.8 & 3.9 \\
\hline Sweet corn & 15.6 & 9.8 & Other & 5.8 & 3.9 & Other & 13.7 & 3.9 \\
\hline Onion & 25.4 & 9.8 & & & & & & \\
\hline White potato & 19.6 & 9.8 & & & & & & \\
\hline Sweet potato & 17.6 & 9.8 & & & & & & \\
\hline Other & 25.5 & 25.5 & & & & & & \\
\hline
\end{tabular}

survey did not ask respondents for their favored organic vegetable, previous surveys indicated that tomatoes are one of the top favorites in organic vegetables (Stevens-Garmon et al. 2007). Farmers indicted that they also produced other vegetables, herbs, fruits, and hay. The produce in the other category were as follows: asparagus, pumpkin, soybean, kale, turnip, squash, green peas, garlic, edamame, broccoli, cauliflower, and lima beans for vegetables; parsley, sage, lemon balm, lemon grass, patchouli, and mint for herbs; and grapes and fig for fruits.

Farmer's knowledge of organic practices

When farmers were asked to rate their knowledge of organic practices using a three-point Likert type scale of $1-3$, where 1 was no knowledge, 2 was some knowledge, and 3 was high knowledge, more than $60 \%$ of them indicated at least some knowledge about production costs, marketing, farming practices, and quality of organic crops (Table 5). Fewer farmers had at least some knowledge for growing organic and almost $50 \%$ reported that they had no knowledge about these practices. Moreover, the overall level of organic knowledge among all respondents averaged below some knowledge for each of the categories assessed and therefore should be increased. This indicates a need to provide information to help farmers interested in adopting organic practices. These results reflect a similar trend of the need for organic education of farmers in other regions such as noted in the survey of Suvedi et al. (2010).

Farmer's barriers to organic practices

The farmers in this project identified several barriers for not growing organic crops. Lack of time (90\%) and the length of time required to certify for organic farming (75\%) were the two most cited reasons for them not growing organic crops (Table 6). The 3-year period necessary for attaining certification and using the USDA certified organic seal, according to guidelines

Table 5 Farmers rating of their knowledge about growing organic crops $(N=49)$

\begin{tabular}{lllll} 
Do you know about? & \multicolumn{2}{l}{ Knowledge } & \multicolumn{2}{c}{ Mean \pm SD } \\
\cline { 2 - 4 } & $\begin{array}{l}\text { None } \\
\%\end{array}$ & Some & High & \\
& & & \\
\hline $\begin{array}{c}\text { Cost of growing organic crops } \\
\text { Market for producing organic }\end{array}$ & 36.6 & 59.2 & 12.2 & $1.81^{\mathrm{a}} \pm 0.61$ \\
$\quad$ crops & 47.0 & 16.3 & $1.77 \pm 0.69$ \\
$\begin{array}{c}\text { Farming practices for safety of } \\
\text { organic grown produce }\end{array}$ & 28.6 & 57.1 & 14.3 & $1.85 \pm 0.62$ \\
$\begin{array}{c}\text { Quality of organic grown } \\
\text { crops }\end{array}$ & 22.5 & 61.2 & 16.3 & $1.94 \pm 0.60$ \\
$\begin{array}{c}\text { Practices for growing certified } \\
\text { organic crops }\end{array}$ & 46.9 & 34.7 & 18.4 & $1.71 \pm 0.74$ \\
\hline
\end{tabular}

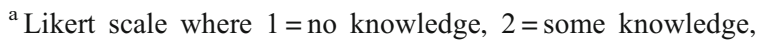
3 = high knowledge 
Table 6 Farmers' response to selected statements for their not growing organic crops $(N=20)$

\begin{tabular}{ll}
\hline Statements & Response (\%) \\
\hline Weaknesses & 35 \\
$\quad$ Have not thought about it & 45 \\
Do not know how to start & 45 \\
Growing organic crops costs too much & 90 \\
Lack of time & 2 \\
Refuse to grow organic & \\
Threats & 35 \\
$\quad$ Consumers' willingness to pay for & \\
$\quad$ organic product is low & 15 \\
$\quad \begin{array}{l}\text { Shoppers prefer conventionally } \\
\text { grown products over organic product }\end{array}$ & 45 \\
Few consumers will pay a high price & \\
$\quad$ for organic crops & 75 \\
$\quad$ Length of time to certify organic farming site & \\
\hline
\end{tabular}

(NOP 2011), is perceived as a threat to their adoption of these practices. However, some producers may gross less than $\$ 5000$ annually in organic sales and thus qualify for producing organic that does not receive a certified seal. In this case, they can qualify for exemption from certification and not prepare an organic systems plan while still complying with all other USDA organic regulations. For those using the certification route, the opportunity for some financial relief is available through Organic Certification Cost Share Programs which assist certified organic operations in defraying a percent of the costs associated with organic certification (USDA 2015). Other weaknesses and threats to adopting organic practices were farmers not knowing how to start, the belief that production cost will be too high, and that few consumers will be willing to pay the high price for organic crops. The views of these farmers echo similar sentiments of farmers' challenges in others regions to adopt organic farming because of high managerial costs, limited awareness of organic farming systems, lack of information on organic production, lack of farm management skills, and marketing challenges (Agunga and Igodan 2007; Farmer et al. 2014; Middendorf 2007) .

Farmers' and non-farmers' organic perceptions and use/preference

All respondents rated their beliefs about selected characteristics of organic crops, specifically fruits, vegetables, and herbs. A two-way ANOVA to test whether there were differences between the responses of the 51 farmers and 20 non- farmers about the safety, quality, and cost of organic produce was conducted and did not find any significance $(P=0.642,0.169$, and 0.704 , respectively). Therefore, the results were pooled (Table 7). Their overall belief that organic produce are safe, high quality, and costly was above low and trending to high, particularly for being costly. They had a high belief that organic crops are safe $(52.9 \%)$, high quality $(52.9 \%)$, and high cost $(68.1 \%)$. Their perceptions of safety, high quality, and healthfulness are in line with national (Onyango et al. 2007; OTA 2015) and other regional (Yue and Tong 2009; Guilabert and Wood 2012) and global (Pearson et al. 2010; Berlin et al. 2009) findings. The beliefs of both the farmers and non-farmers that organics are expensive also confirm results of earlier studies (Dimitri and Oberholtzer 2009; Byrne et al. 1992; Raab and Grobe 2005) that high cost of organics is a negative perception of consumers and presents an affordability challenge when buying organic produce.

Farmers and non-farmers had similar response $(P=0.0864)$ about their usage of organics (Table 8). More than $50 \%$ of respondents sometimes used

Table 7 Farmers and non-farmers combined level of beliefs about organic produce characteristics $(N=71)$

\begin{tabular}{|c|c|c|c|c|c|}
\hline \multirow[t]{2}{*}{ Characteristics } & \multicolumn{4}{|l|}{ Belief } & \multirow[t]{2}{*}{$\operatorname{Mean}^{\mathrm{b}} \pm \mathrm{SD}$} \\
\hline & $\begin{array}{l}\text { NoOp }{ }^{\mathrm{a}} \\
\%\end{array}$ & Zero & Low & High & \\
\hline Safe from harmful chemicals and human pathogens & 4.4 & 7.4 & 35.3 & 52.9 & $3.37 \pm 0.81$ \\
\hline High quality, healthy, and nutritious & 16.2 & 10.3 & 20.6 & 52.9 & $3.10 \pm 1.11$ \\
\hline Costly & 16.2 & 4.3 & 23.2 & 68.1 & $3.56 \pm 0.78$ \\
\hline
\end{tabular}

${ }^{\mathrm{a}} \mathrm{NoOp}$ no opinion

${ }^{\mathrm{b}}$ Likert scale where 1 = no opinion, 2 = zero belief, $3=$ low belief, $4=$ high belief 
Table 8 Farmer and non-farmer combined rating of their use and preference for organics $(N=69)$

\begin{tabular}{lll} 
Rate your use and preference of organic crops & Frequency $(\%)$ \\
\hline Use & A lot- $3^{\text {a }}$ & 15.9 \\
& Sometimes-2 & 63.8 \\
& Never-1 & 20.3 \\
Preference & & \\
& Yes & 60.0 \\
& No & 40.0 \\
\hline & &
\end{tabular}

${ }^{\mathrm{a}}$ Combined farmer and non-farmer rating average was $1.96 \pm 0.60$

organics and only $15 \%$ used them a lot. This low percent for habitual users corroborates with a national report of only $22 \%$ of US population consuming organics daily (Lester 2006); the much higher percent of occasional users is in agreement with the report of Greene 2014 that organic products are being consumed at least occasionally by a majority of Americans. The preference of farmers and non-farmers for organics was also similar $(P=0.3874)$. Inclusive of farmers and nonfarmers, more than half of them preferred organics.

Farmers' and non-farmers' organic needs and comments

To determine the needs of the farmers who were not involved in organic production or non-farmers who desired to do so, respondents were asked to list three needs that would help them to start growing organic crops. Thirty-seven percent of the farmers were not involved in organic production, and $25 \%$ of the non-farmers indicated a desire for doing so. The total list of needs for the two groups was 58 and was grouped into seven categories (Table 9). Overall, their most frequent need for information fell in three categories: production inputs and techniques, costs, and marketing. All interested respondents needed information on production techniques and inputs. This category included information such as availability of affordable organic supplies, how to use organic mulch, how to prepare and use compost safely, other fertilizer needs and options, soil preparation, and pest management.

In the final question, an open-ended one, respondents were asked to provide any additional comments. Their responses included skepticism on whether organic produce is truly organic, concerns and need for pest
Table 9 Needs of non-organic farmers and non-farmers wanting to grow organic

\begin{tabular}{lll}
\hline Information needed $^{\mathrm{a}}$ & $\begin{array}{l}\text { Farmers } \\
(n=19 \\
\text { Percent responded (\%) }\end{array}$ & $\begin{array}{l}\text { Non-farmers } \\
(n=5)\end{array}$ \\
\hline Marketing & 26.3 & 60.0 \\
Cost/expenses & 47.4 & 20.0 \\
Profitability & 15.8 & 20.0 \\
$\begin{array}{l}\text { Production inputs and } \\
\text { techniques }\end{array}$ & 100 & 100.0 \\
$\begin{array}{l}\text { Getting started } \\
\text { Organic certification }\end{array}$ & 10.5 & 20.0 \\
$\quad$ guidelines & 26.3 & 20.0 \\
Healthy and natural foods & 10.5 & 0
\end{tabular}

${ }^{\mathrm{a}}$ Each respondent submitted no more than 3 needs

protection, and questioning of whether organics are more nutrient rich and healthier than non-organics. Samples of some direct comments are as follows: "Find a way to grow organic crops on a large scale in a more environmentally friendly way (i.e., reduced tillage and reduced constant use of poultry litter and other manures). Due to high $\mathrm{P}$ level of poultry litter and other manures, this practice of organic growers using this as fertilizer is not sustainable. Due to mold board plow and cultivating to reduce weed pressure, soil organic matter is depleted over time. Large scale organic growers cannot afford to grow 1 year in 3 or 4 of a clover or other clover to increase organic matter. There is a public disconnect in understanding about organic production. People who don't understand farming think organic $=$ better for the environment. With current agronomic organic practices I believe that this 'mass' belief to be unfounded." "Not interested in organic, seems like too much work that I did as a kid growing up."

\section{Conclusions}

This survey of limited resource farmers and non-farmers on the Delmarva and neighboring counties revealed that the majority of farmers had been farming for at least 5 years. Livestock and crops were their most popular commodities produced. Fewer than $30 \%$ produced a mixture of organic and non-organic crops and less than $10 \%$ produced only organic crops. However, a third of them produced organic fruits and vegetables. This low percentage indicates room for expansion for farmers 
who have an interest in growing organic. With the consumer group, inclusive of both farmers and nonfarmers, expressing a desire for more organics over non-organics, this supports a likelihood of growing market for organics. Since some non-organic farmers and some non-farmers also express an interest in growing organic, their needs for production will need to be addressed. The needs include information on inputs and production techniques, costs, and marketing information. While farmers' overall responses affirmed that they had some level of knowledge on organics, there were nearly as many who did not know about certified organic practices as the approximately $50 \%$ who did. More outreach education is needed to assist them. Overall opinion of the respondents was favorable on the safety and quality of organic produce. They preferred organic over non-organic and already were using some organic crops. This further confirms the opportunity for markets to expand and the need for more assistance for current and potential farmers with organic production on the Delmarva Peninsula. While there are some similarities in the perception of this sample group to those from other regions, the recommendations from this survey cannot be generalized to other regions due to the small sample size of 71 . However, their expressed desire to use and or grow organic, while highlighting concerns about the regulatory time and other resources necessary for producing organics, suggests a continued need for policies to make organic production more amenable to adoption by producers.

Open Access This article is distributed under the terms of the Creative Commons Attribution 4.0 International License (http://creativecommons.org/licenses/by/4.0/), which permits unrestricted use, distribution, and reproduction in any medium, provided you give appropriate credit to the original author(s) and the source, provide a link to the Creative Commons license, and indicate if changes were made.

\section{References}

Agunga R, Igodan C (2007) Organic farmers need and attitude towards extension. J Ext 45(6). (http://www.joe.org/joe/ 2007december/a6.php). Accessed 24 Jan 2015

Berlin L, Lockeretz W, Bell R (2009) Purchasing foods produced on organic, small and local farms: a mixed method analysis of New England consumers. Renew Agric Food Syst 24:267-275

Byrne PJ, Toensmeyer UC, German CL, Muller HR (1992) Evaluation of consumer attitudes towards organic produce in Delaware and the Delmarva region. J Food Distrib Res 23: 29-44

Dimitri C, Oberholtzer L (2009) Marketing U.S. organic foods: recent trends from farms to consumers. Economic Information Bulletin No.58. Economic Research Service/ USDA

ERS (Economic Research Service) (2014) Organic market overview. (http://www.ers.usda.gov/topics/natural-resourcesenvironment/organic-agriculture/organic-market-overview. aspx). Accessed 24 Jan 2016

EUFIC (European Food Information Council) (2013) Organic food and farming: the scientific facts and consumer perceptions. (http://www.eufic.org/article/en/expid/Organic_food and_farming_scientific_facts_and_consumerperceptions/). Accessed 24 Jan 2016

Farmer J, Epstein G, Watkins S, Mincey S (2014) Organic farming in West Virginia: a behavioral approach. J Agric Food Syst Commun 4:155-171. doi:10.5304/jafscd.2014.044.007, Accessed 25 Jan 2016

Greene C (2013) Growth patterns in the U.S. organic industry. (http://www.ers.usda.gov/amber-waves/2013-october/ growth-patterns-in-the-us-organic-industry.aspx). Accessed 24 Jan 2016

Greene C (2014) Organic market overview. (http://www.ers.usda. gov/topics/natural-resources-environment/organicagriculture/organic-market-overview.aspx). Accessed 24 Jan 2016

Guilabert M, Wood J (2012) USDA certification of food as organic: an investigation of consumer beliefs about the health benefits of organic food. J Food Prod Mark 18(5):353-368. doi:10.1080/10454446.2012.685028

Hoppe R, Korb P, O’Donoghue E, Banker D (2007) Structure and finances of U.S. farms, family farm report, 2007 edn. Economic Information Bulletin Number 24, U.S. Department of Agriculture, Economic Research Service, 2007

Lester GE (2006) Organic versus conventionally grown produce: quality differences, and guidelines for comparison studies. HortSci 41:296-300

Middendorf G (2007) Challenges and information needs of organic growers and retailers. J Ext 45(4). (http://www.joe.org/joe/ 2007august/a7.shtml). Accessed 24 Jan 2016

(NOP) National Organic Program (2011) Organic production and handling standards. (http://www.ams.usda.gov/sites/default/ files/media/Organic\%20Production-Handling\%20Standards. pdf). Accessed 24 Jan 2016

Onyango BM, Hallman WK, Bellows AC (2007) Purchasing organic food in US food systems: a study of attitudes and practice. Br Food J 109(5):399-411

OTA (Organic Trade Association) (2015) Market analysis. (http:// www.ota.com/organic/mt/business.html). Accessed 24 Aug 2015

Pearson D, Henryks J, Jones H (2010) Organic food: what we know (and do not know) about consumers. Renew Agric Food Syst 26:171-177

Raab C, Grobe D (2005) Consumer knowledge and perceptions about organic food. J Ext 43:4, (http:/www.joe.org/joe/ 2005august/rb3.php). Accessed 24 Jan 2016

Shafie F, Rennie D (2012) Consumer perceptions towards organic food. Procedia - Soc Behav Sci 49:360-367, (http://www. 
sciencedirect.com/science/article/pii/S1877042812031308). Accessed 24 Jan 2016

Stevens-Garmon J, Huang CL, Lin BH (2007) Organic demand: a profile of consumers in the fresh produce market. Choices 22(2):109-116

Suvedi M, Jeong E, Coombs J (2010) Education needs of Michigan farmers. J Ext 48(3). (http://www.joe.org/joe/ 2010june/rb7.php). Accessed 24 Jan 2016
USDA (2015) Organic certification cost share programs. (http:// www.ams.usda.gov/services/grants/occsp). Accessed 25 Jan 2016

Yue C, Tong C (2009) Organic or local? Investigating consumer preference for fresh produce using a choice experiment with real economic incentives. HortSci 44:366-371 